\title{
Effects of climate change and industrialization on Lake Bolshoe Toko, eastern Siberia
}

\author{
Boris K. Biskaborn $(\mathbb{D} \cdot$ Biljana Narancic $\mathbb{( \mathbb { C }} \cdot$ Kathleen R. Stoof-Leichsenring $(\mathbb{D} \cdot$ \\ Lyudmila A. Pestryakova (1) - Peter G. Appleby (D) - Gayane T. Piliposian • \\ Bernhard Diekmann
}

Received: 4 June 2020/ Accepted: 7 January 2021 / Published online: 23 January 2021

(C) The Author(s) 2021

\begin{abstract}
Industrialization in the Northern Hemisphere has led to warming and pollution of natural ecosystems. We used paleolimnological methods to explore whether recent climate change and/or pollution had affected a very remote lake ecosystem, i.e. one without nearby direct human influence. We compared sediment samples that date from before and after the onset of industrialization in the midnineteenth century, from four short cores taken at water depths between 12.1 and $68.3 \mathrm{~m}$ in Lake Bolshoe Toko, eastern Siberia. We analyzed diatom assemblage changes, including diversity estimates, in all four cores and geochemical changes (mercury, nitrogen, organic carbon) from one core taken at an
\end{abstract}

Electronic supplementary material The online version of this article (https://doi.org/10.1007/s10933-021-00175-z) contains supplementary material, which is available to authorized users.

B. K. Biskaborn $(\bowtie) \cdot$ B. Narancic .

K. R. Stoof-Leichsenring · B. Diekmann

Alfred Wegener Institute Helmholtz Centre for Polar and Marine Research, Potsdam, Germany

e-mail: boris.biskaborn@awi.de

\section{B. Narancic}

Laboratoire de Paléoécologie Aquatique, Centre d'Études nordiques and Département de géographie, Université

Laval, Quebec City, Canada

L. A. Pestryakova

North-Eastern Federal University of Yakutsk, Yakutsk,

Russia intermediate water depth. Chronologies for two cores were established using ${ }^{210} \mathrm{~Pb}$ and ${ }^{137} \mathrm{Cs}$. Sedimentation rates were 0.018 and $0.033 \mathrm{~cm}_{\text {year }}{ }^{-1}$ at the shallowand deep-water sites, respectively. We discovered an increase in light planktonic diatoms (Cyclotella) and a decrease in heavily silicified euplanktonic Aulacoseira through time at deep-water sites, related to more recent warmer air temperatures and shorter periods of lake-ice cover, which led to pronounced thermal stratification. Diatom beta diversity in shallow-water communities changed significantly because of the development of new habitats associated with macrophyte growth. Mercury concentrations increased by a factor of 1.6 since the mid-nineteenth century as a result of atmospheric fallout. Recent increases in the chrysophyte Mallomonas in all cores suggested an acidification trend. We conclude that even remote

\author{
P. G. Appleby · G. T. Piliposian \\ Environmental Radioactivity Research Centre, \\ Department of Mathematical Sciences, University of \\ Liverpool, Liverpool, UK \\ B. Diekmann \\ Institute of Environmental Science and Geography, \\ University of Potsdam, Potsdam, Germany
}


boreal lakes are susceptible to the effects of climate change and human-induced pollution.

Keywords Diatoms - Recent climate change · Mercury · Lake sediment cores · Human impact

\section{Introduction}

In the debate about the role of humans in changing our environment, it is necessary to study the role of natural processes versus the impact of anthropogenic activities. The overwhelming role of human activity basically comprises two aspects: (1) climate change from enhancement of atmospheric greenhouse gases by combustion of fossil fuels, and (2) pollution of the natural environment by industrialization and other activities associated with human population growth (IPCC 2018). Whereas atmospheric change acts mainly at a global scale, the impact of pollution occurs mainly at regional and local scales. Global influences on the environment can be recognized in pristine ecological systems that are not directly affected by local anthropogenic activities, such as in the vast boreal areas of the Northern Hemisphere (Jones et al. 2015).

Since the onset of industrialization in the midnineteenth century, accelerated increases in air temperature (Abram et al. 2016) and human land-use have induced ecological consequences in northern freshwater ecosystems (AMAP 2017). Boreal and highelevation regions are particularly sensitive to climate change because of strong snow albedo and surfacebased feedbacks (Pepin et al. 2015). Over the past decades, Russian landscapes have experienced faster warming than sites elsewhere (Biskaborn et al. 2019b). In these regions, lakes are effective sentinels of environmental change that rapidly integrate information about catchment changes.

Climate change is altering physicochemical and biological lake properties (Heinecke et al. 2017; Vyse et al. 2020; Wang et al. 2015). The cumulative effect of warmer air temperature on Russian lake ecosystems and the role of local factors that influence lake catchment responses remain unclear. Understanding the amplitude of lake responses to global and local environmental changes is crucial for the sustainability of these fragile ecosystems. A powerful approach for deciphering the impacts of climate change and industrialization on these remote northern lakes is paleolimnology. To infer changes, lake-sediment cores are dated and analyzed for biological remains and physicochemical properties (Cohen 2003).

In northern lakes, diatoms (unicellular siliceous algae) often represent the main aquatic primary producers. Their opaline frustules are well preserved in the sediment record (Battarbee et al. 2001) enabling identification at the species level. The presence and variety of diatom taxa in aquatic environments are linked to the physicochemical variables of water (e.g. light, temperature, nutrients, $\mathrm{pH}$, salinity, and the content of oxygen and organic matter) (Smol and Stoermer 2010; Van Dam et al. 1994). Collectively, these characteristics make diatoms effective indicators of environmental change and are especially useful bioindicators in cold-region water bodies such as the Russian boreal lakes (Biskaborn et al. 2012, 2016; Hoff et al. 2015; Huang et al. 2020; Palagushkina et al. 2017). Moreover, widespread responses of planktonic taxa to anthropogenic warming indicate that northern lakes have already crossed sensitive ecological thresholds (Rühland et al. 2008; Smol and Douglas 2007).

One of the well-known effects of industrialization in the Northern Hemisphere is acidification of lakes as a consequence of the emission, transport, and deposition of sulfuric and nitric acid aerosols by river input or directly from the atmosphere (Farmer 1990). Atmospheric fallout of anthropogenic pollutants, including heavy metals, leads to contamination of soils and subaquatic substrates. Historically emitted mercury $(\mathrm{Hg})$ is a well-established tracer of heavymetal pollution in lakes (Jones et al. 2015; Wang et al. 2004). Although it is mainly adsorbed to sediment, it is still a dangerous threat to aquatic ecosystems and can affect the composition of, for example, diatom assemblages (Pérès et al. 1997). Modern atmospheric $\mathrm{Hg}$ accumulation in lake beds of remote and formerly pristine aquatic systems is a strong sign of contamination, and can be up to 24 times higher than preindustrial levels (Lamborg et al. 2002; Wang et al. 2004).

Lake Bolshoe Toko is possibly the deepest large lake in Yakutia, eastern Russia (Zhirkov et al. 2016). The lake is considered a pristine system to study the impact of environmental changes without direct anthropogenic activity (Biskaborn et al. 2019a). As shown in this and other studies, within-lake 
distributions of environmental indicators such as microfossils differ across space, and mixing processes do not homogenize the microfossil assemblages before deposition in such large lakes (Stewart and Lamoureux 2012). It is therefore possible to study the different responses to external environmental changes in deepand shallow-water habitats (Biskaborn et al. 2019a).

In this study, our primary goal was to assess the effects of global climate change and industrialization on remote Lake Bolshoe Toko. We also sought to examine if climate change after the mid-nineteenth century affected diatom assemblages, and if there were different responses in deeper and shallower water communities related to species habitat preferences. Therefore, the objectives of this study were to: (1) reconstruct diatom communities from sediment cores taken at different water depths, to evaluate differences before and after the onset of industrialization and (2) discover whether there was a change in sediment geochemical composition related to post-industrial human activity such as air temperature warming, or heavy metal pollution.
Study site

Lake Bolshoe Toko (Russia, Sakha Republic, 56 ${ }^{\circ} 15^{\prime}$ $\mathrm{N}, 130^{\circ} 30^{\prime} \mathrm{E}, 903$ masl) is a deep oligotrophic freshwater lake, $15.4 \mathrm{~km}$ long and $7.5 \mathrm{~km}$ wide, with a surface area of about $84.3 \mathrm{~km}^{2}$ and a maximum water depth of $72.5 \mathrm{~m}$ (Fig. 1). The lake is fed by the Utuk River, which runs through Lake Maloe Toko and brings water from the southern igneous catchment of the Stanovoy Mountains. Historical documents for the region suggest that no permanent settlement was ever established in the study area, although a temporary mining settlement located $17 \mathrm{~km}$ northwest of the lake (Fig. 1) was built in $2011 \mathrm{CE}$ and was still active at the time of our sampling campaign in 2013. The El'ginsky coal deposits will likely cause future impact to the lake ecosystem and its catchment (Konstantinov 2000; Sobakina and Solomonov 2013).

The study area is situated in the East Siberian boreal forest, within the continental temperate climate zone and a predominant westerly wind system (Shahgedanova 2002). About $8 \mathrm{~km} \mathrm{NNE}$ of the lake, the Toko RS meteorological station $\left(131^{\circ} 01^{\prime} \mathrm{E}, 56^{\circ} 10^{\prime} \mathrm{N}\right.$, WMO code 31137 ) has collected data on temperature and precipitation since $1960 \mathrm{CE}$, which were used in our study to validate the most recent climate trends. a



b



Fig. 1 Location of Lake Bolshoe Toko. a Overview map. b Map of Lake Bolshoe Toko showing location of the four short sediment cores retrieved in $2013 \mathrm{CE}$, the lake bathymetry based on Konstantinov (2000) and slightly modified from Biskaborn et al. (2019a) to fit the measured water depths at sites, and topographic features based on Kornilov (1962) 
The lake basin is of tectonic and glacial origin, adjoined to the northern slope of the eastern Stanovoy Mountain Range (Imaeva et al. 2009). The catchment is characterized by Precambrian igneous rocks in the south and Mesozoic sandstones and mudstones in the north. The northern part of the lake is bordered by moraines of three different glacial sub-periods (Kornilov 1962) (Fig. 1).

Bolshoe Toko Lake was described as a clean, oligotrophic, fresh, and clear lake with a transparency of 5.5-9.8 m (Genkal and Gabyshev 2018; Zhirkov et al. 2016). Biskaborn et al. (2019a) provided mean values for $\mathrm{pH}(7.0)$, conductivity $\left(42.5 \mu \mathrm{S} \mathrm{cm}^{-1}\right)$, oxygen saturation $(108 \%), \mathrm{HCO}_{3}{ }^{-}\left(18.7 \mathrm{mg} \mathrm{l}^{-1}\right)$ $\delta^{18} \mathrm{O}(-18.7 \%)$, phosphate $\left(<0.1 \mathrm{mg} \mathrm{l}^{-1}\right)$, nitrate $\left(0.8 \mathrm{mg}^{-1}\right)$ among other anions and cations from six relatively uniform water samples collected at different sites in the lake. The lake zooplankton consists of about 20 species, of which $40 \%$ are rotifers, $35 \%$ are cladocerans, and 25\% are copepods (Sobakina and Solomonov 2013). The diatom phytoplankton taxonomy in the surface water was described in detail by Genkal and Gabyshev (2018), and revealed a new and dominant species, Pliocaenicus bolshetokoensis (Genkal et al. 2018), as part of diatom assemblages characterized mainly by Cyclotella (sensu lato) and Aulacoseira species.

\section{Materials and methods}

Fieldwork

In a collaboration between the Alfred Wegener Institute Helmholtz Centre for Polar and Marine Research (AWI) and the North Eastern Federal State University in Yakutsk (NEFU), we conducted fieldwork between 19 March and 14 April 2013, as part of the German-Russian expedition "Yakutia 2013." To retrieve short sediment cores, we drilled 250-mmdiameter holes in the ice cover using a Jiffy ice auger. Water depth was measured using a portable Echo sounder (HONDEX PS-7 LCD) and a calibrated rope for verification. We retrieved short cores from different sites in the lake at different water depths using a UWITEC gravity corer (Fig. 1, ESM Table 4). We selected four cores for study, taken at shallow, intermediate and deep sites, to explore the responses of diatom communities to climate change, as related to lake bathymetry. We subsampled them onsite to avoid sediment mixing during transport. Sediment samples were transported in sterile Whirl-Pak ${ }^{\mathrm{TM}}$ bags to the AWI laboratories in Germany and stored at $4{ }^{\circ} \mathrm{C}$ in a dark room prior to freeze-drying and analyses. Hydrochemical measurements were performed during fieldwork and are given in detail in Biskaborn et al. (2019a).

\section{Dating}

Chronologies were developed for short cores PG2139 and PG2203 by measuring ${ }^{210} \mathrm{~Pb},{ }^{226} \mathrm{Ra},{ }^{137} \mathrm{Cs}$ and ${ }^{241} \mathrm{Am}$ activities in freeze-dried sub-samples by direct gamma assay in the Liverpool University Environmental Radioactivity Laboratory, using Ortec HPGe GWL series well-type coaxial low background intrinsic germanium detectors (Appleby et al. 1986). Counting times varied from 1 to 3 days depending on the activity of the sample. The criterion used was the number of ${ }^{210} \mathrm{~Pb}$ counts, generally at least 500 for sufficient accuracy. ${ }^{210} \mathrm{~Pb}$ was determined via its gamma emissions at $46.5 \mathrm{keV}$, and ${ }^{226} \mathrm{Ra}$ by the $295 \mathrm{keV}$ and $352 \mathrm{keV}$ gamma rays emitted by its daughter radionuclide ${ }^{214} \mathrm{~Pb}$, following 3 weeks storage in sealed containers to allow radioactive equilibration. ${ }^{137} \mathrm{Cs}$ and ${ }^{241} \mathrm{Am}$ were measured by their emissions at $662 \mathrm{keV}$ and $59.5 \mathrm{keV}$, respectively. The absolute efficiencies of the detectors were determined using calibrated sources and standard sources of known activity. Corrections were made for the effect of self-absorption of low-energy gamma rays within the sample (Appleby et al. 1992).

\section{Diatom analysis}

We analyzed diatoms in 0.5 -cm sediment slices taken from short cores, between the sediment surface $(0 \mathrm{~cm})$ and down to as much as $13 \mathrm{~cm}$ core depth. Samples were collected from the following four cores, each taken at a different water depth: PG2208 (68.3 m), PG2203 (36.1 m), PG2133 (26.0 m), and PG2139 $(12.1 \mathrm{~m})$. In total, 26 samples, each $0.1 \mathrm{~g}$ dry sediment, were retrieved from the sediment cores for diatom analysis. Each sample spanned $0.5 \mathrm{~cm}$ in the core, except for core PG2133, which had 1-cm slices removed above 4 and below $6.5 \mathrm{~cm}$. Diatom slides were prepared and analyzed for species assemblages following standard procedures (Battarbee et al. 2001). 
We treated all samples with hydrogen peroxide for removal of organic matter and added $5 \times 10^{6}$ microspheres to estimate diatom valve concentration (DVC). For species identification, we used several diatom floras, including Hofmann et al. (2011) and Krammer and Lange-Bertalot (1986-1991). For rare and endemic taxa, we conducted a literature search, which included Genkal et al. (2018) for Pliocaenicus. A minimum of 300 (but up to 361) valves were counted in each sample, except one, using a Zeiss AXIO Scope.A1 light microscope with a PlanApochromat $100 \times / 1.4$ Oil $\mathrm{Ph} 3$ objective at $1000 \times$ magnification. Identifications of small species were validated with a scanning electron microscope (SEM) at the GeoForschungsZentrum Potsdam. In the sample from 8.5 to $8.0 \mathrm{~cm}$ in core PG2203, diatoms were scarce and only 204 valves could be counted. Diatom valve preservation was estimated while counting and calculated as the "F-index" (Ryves et al. 2001). In all samples, scales of the chrysophyte Mallomonas were counted along with diatom valves, but not identified to species level. The Mallomonas index, i.e. Mallomonas relative to diatom cells, was estimated to assess lake acidification, following Smol (1984).

For simplicity, we use "Cyclotella" as a descriptor for Cyclotella (sensu lato) in a classical sense (Krammer and Lange-Bertalot 1986-1991), including species that recently have been attributed to Lindavia or Pantocsekiella in taxonomic studies (Ács et al. 2016; Nakov et al. 2015) (ESM Table 2).

The change in relative abundance of Cyclotella (sensu lato), and two groups of Aulacoseria taxa (group 1: A. distans \& A. valida and group 2: A. ambigua, A. subarctica) at the onset of industrialization was calculated by subtracting mean percentages in bottom samples (before $\sim 1850 \mathrm{CE}$ ) from the mean in top samples (after $\sim 1850 \mathrm{CE}$ ) for each core. According to the number of samples present and inferred accumulation rates, samples used to calculate means varied (top versus bottom samples as indicated red and blue in Fig. 3: PG2208: 4 vs. 4, PG2203: 3 vs. 3, PG2133: 2 vs. 2, PG2139: 2 vs. 2). To exclude the influence of earlier climate fluctuations, before the pre-industrial conditions, from the calculations, we did not extrapolate dates from ${ }^{210} \mathrm{~Pb}$ age model, but estimated sedimentation rates instead to infer a higher bottom-boundary for the samples from shallow-water sites.
There is no ${ }^{210} \mathrm{~Pb}$ age model available for cores PG2208 and PG2133, therefore we used the dated cores (PG2139 and PG2203) to estimate approximate ages in the undated cores, using lithological similarities between the two deepest cores (PG2208, PG2203) and the two shallowest cores (PG2133, PG2139).

\section{Organic geochemistry}

To assess the accumulation of organic matter in the lake, we analyzed total organic carbon (TOC) and nitrogen $(\mathrm{N})$ in 61 freeze-dried and milled samples from the top $30.5 \mathrm{~cm}$ of short core PG2203 (Fig. 1) using a Vario EL III CNS and a Vario MAX C analyser. The measurement accuracy was $0.1 \mathrm{wt} \%$ for both TOC and TN. To gain additional information about the productivity, we analyzed stable organic carbon isotopes $\left(\delta^{13} \mathrm{C}\right)$ in 61 samples using a Finnigan Delta-S mass spectrometer. Results are presented as $\delta^{13} \mathrm{C}$ values relative to the PDB standard (\%o) with an error of $\pm 0.15 \%$. The information on carbon chemistry is provided at a resolution of $0.5 \mathrm{~cm}$ in the short core.

Inorganic geochemistry

To characterize the chemical variability of the lake sediment in historical times, we analyzed samples from dated short core PG2203, taken at intermediate water depth. This site is located in the central part of the lake, at a depth close to the average water depth for the whole lake, and thus is believed to best represent the sediment chemical properties (Fig. 1). For analysis of heavy metal pollution, we used mercury $(\mathrm{Hg})$ concentrations. We sent 14 samples from sediment core PG2203 to the chemical-analytical laboratory of Vinogradov Institute of Geochemistry, Siberian Branch of the Russian Academy of Science (IGC SB RAS). The laboratory measured mass fraction of total mercury using an RP-91S/RA-915 + mercury analyzer. Total sedimentary mercury was detected by atomization of mercury in a two-section pyrolyzer and subsequent determination by the flameless atomic absorption method with the mercury analyzer. Measurement error was 0.03-0.06 ppm and is shown next to the data. 
Statistical analyses

For multivariate statistical processing of diatom data we used the $\mathrm{R}$ environment ( $\mathrm{R}$ Core Team 2016). A constrained incremental sum-of-squares clustering (CONISS) on all species counts was performed after chi-squared standardization and use of the BrayCurtis dissimilarity index. A principal component analysis (PCA) was performed on species data after filtering out rare species. Only species with $\geq 10$ valve counts in $\geq 2$ samples were kept in the dataset for PCA and included in the species distribution diagrams and biplots of the first two principal components (ESM Fig. 1-4). We chose PCA as a suitable ordination method because the gradient length was below 2.5 standard deviation (SD) units (Birks 2010), as determined by detrended correspondence analysis (DCA). PCA was performed using the 'prcomp' function in the basic $\mathrm{R}$ package 'stats'. DCA was performed using the function 'decorana' in the package 'vegan' (Oksanen et al. 2012). DCA axis lengths from the core datasets are as follows (in SD units): PG2208 = 0.93; PG2203 = 1.18; PG2133= $1.25 ; \mathrm{PG} 2139=1.57$. The total variances of the core datasets explained by the first two principal components derived from the PCA are: PG2208 $=61.05 \%$; PG2203 $=81.67 \% ; \quad P G 2133=69.43 \% ;$ $\mathrm{PG} 2139=69.22 \%$.

Diatom species richness was estimated after sample-size normalization, using a rarefaction analysis of Hill numbers in the iNEXT package (Hsieh et al. 2016). To estimate the rate of change of species composition between samples, we estimated beta diversity using the function beta.div in the $\mathrm{R}$ package 'adespatial' (Dray et al. 2016). This function estimates the total beta diversity (BDTotal) from the total variance in the community data and decomposes the BDTotal into local contributions to beta diversity (LCBD). Adjusted $p$ values were estimated using the 'Holm' correction method in the same $\mathrm{R}$ package (ESM Table 3). Prior to the estimation of beta diversity, count data were transformed using Hellinger dissimilarity. Relative changes for other sediment variables, as a consequence of industrialization were calculated using an approach similar to that used for diatom taxa, that is, by subtracting the mean of samples before $\sim 1850 \mathrm{CE}$ from the mean of samples after $\sim 1850 \mathrm{CE}$ for each core.

\section{Results}

Dating

Sedimentation rates in PG2139 and PG2203 are very low (Fig. 2, Table 1). ${ }^{210} \mathrm{~Pb} /{ }^{226} \mathrm{Ra}$ equilibrium, corresponding to a period of around six ${ }^{210} \mathrm{~Pb}$ half-lives ( $\sim 130$ years), occurs at sediment depths of $<5 \mathrm{~cm}$. In PG2139 the unsupported ${ }^{210} \mathrm{~Pb}$ activity declines exponentially with depth (Fig. 2e), showing that sedimentation rates have remained relatively constant since at least the late nineteenth century. The mean accumulation rate determined from the exponential gradient of the ${ }^{210} \mathrm{~Pb}$ decline is $0.018 \pm 0.002 \mathrm{~cm} \mathrm{year}^{-1}$. A higher accumulation rate of $0.033 \pm 0.006 \mathrm{~cm} \mathrm{year}^{-1}$ in PG2203 (collected from $36.1 \mathrm{~m}$ water depth) is probably a consequence of sediment focusing, as supported by its higher mean ${ }^{210} \mathrm{~Pb}$ supply rate $\left(74 \mathrm{~Bq} \mathrm{~m}^{-2}\right.$ year $\left.^{-1}\right)$ compared to PG2139 (45 $\mathrm{Bq} \mathrm{m}^{-2}$ year $^{-1}$ ).

The ${ }^{210} \mathrm{~Pb}$ dates are in reasonable agreement with the ${ }^{137} \mathrm{Cs}$ results. High concentrations of this artificial radionuclide, generated by the atmospheric testing of thermo-nuclear weapons, were detected in the uppermost $2 \mathrm{~cm}$ of PG2203. Presence at similar depths of low but significant concentrations of ${ }^{241} \mathrm{Am}$, also a product of nuclear weapons fallout, shows that this section of the core includes material from the early 1960s. The ${ }^{210} \mathrm{~Pb}$ dates place 1963 , the year of maximum ${ }^{137} \mathrm{Cs}$ fallout, within the $1.5-2 \mathrm{~cm}$ slice. Highest ${ }^{137}$ Cs concentrations in PG2139 occur in the uppermost $1 \mathrm{~cm}$, reflecting its slower accumulation rate. The ${ }^{210} \mathrm{~Pb}$ dates for this core place $1963 \mathrm{CE}$ within the $0.5-1 \mathrm{~cm}$ slice.

The low resolution of our age models only enables us to estimate the timing of the industrial signal in the lake. Therefore, we performed a top-bottom comparison between pre-industrial and industrial conditions, as reported in the literature for the Northern Hemisphere (Abram et al. 2016; Gabrielli et al. 2020; Holtgrieve et al. 2011). According to this literature, we chose $1850 \mathrm{CE}$ to approximate the onset of industrialization. We are aware of the fact that industrial activity in Europe started as much as 100 years earlier (IPCC 2018). Noticeable effects, however, were delayed (Holtgrieve et al. 2011) and are best expressed since the mid-nineteenth century (Abram et al. 2016). Accordingly, we used the ${ }^{210} \mathrm{~Pb}$ and ${ }^{137} \mathrm{Cs}$ chronologies for cores PG2203 and PG2139 to identify the 



Fig. 2 Fallout radionuclides in Lake Bolshoe Toko sediment core PG2203 showing a total and supported ${ }^{210} \mathrm{~Pb}$, b unsupported ${ }^{210} \mathrm{~Pb}$ and $\mathbf{c}^{137} \mathrm{Cs}$ and ${ }^{241} \mathrm{Am}$ activities versus core depth.

1850 CE boundary between top and bottom samples and projected the boundaries onto cores PG2208 and PG2233.

\section{Diatoms}

Preservation of diatom valves was generally excellent, with a mean F-index of 0.9 , which means $90 \%$ of the valves counted were pristine (Flower and Ryves 2009). In sediment samples from core PG2208
Sediment core PG2139 showing d total and supported ${ }^{210} \mathrm{~Pb}$, e unsupported ${ }^{210} \mathrm{~Pb}$, and $\mathbf{f}{ }^{137} \mathrm{Cs}$ concentrations versus core depth

(Fig. 3a), taken at $68.3 \mathrm{~m}$ water depth, $70 \%$ of diatom valves are planktonic, $25 \%$ are epiphytic, and $5 \%$ are epipelic species (means of all counted samples). Cyclotella taxa are represented by $45.2 \%$ and Aulacoseira by $7.4 \%$, on average. The difference in mean Cyclotella abundance between the upper four samples, from 0 to $2.5 \mathrm{~cm}$, and the lower four samples, from 3 to $13 \mathrm{~cm}$, is $1.4 \%$. The differences from the same sample intervals for Aulacoseira group 1 (A. distans \& A. valida) and Aulacoseira group 2 (A. ambigua, 
Table $1{ }^{210} \mathrm{~Pb}$ dates for Lake Bolshoe Toko sediment cores PG2139 m and PG2203, collected from $12.1 \mathrm{~m}$ and $36.1 \mathrm{~m}$ water depth, respectively

\begin{tabular}{|c|c|c|c|c|c|c|}
\hline \multirow[t]{2}{*}{ Depth } & \multicolumn{3}{|c|}{ PG2139 } & \multicolumn{3}{|c|}{ PG2203 } \\
\hline & Date & Age & & Date & Age & \\
\hline $\mathrm{cm}$ & $\mathrm{CE}$ & Years & \pm & $\mathrm{CE}$ & Years & \pm \\
\hline 0.00 & 2013 & 0 & 0 & 2013 & 0 & 0 \\
\hline 0.25 & 1977 & 36 & 4 & 2007 & 6 & 1 \\
\hline 0.75 & 1948 & 65 & 8 & 1994 & 19 & 3 \\
\hline 1.25 & 1916 & 97 & 11 & 1979 & 34 & 6 \\
\hline 1.75 & 1888 & 125 & 15 & 1962 & 51 & 9 \\
\hline 2.25 & 1858 & 155 & 18 & 1947 & 66 & 12 \\
\hline 2.75 & - & - & - & 1931 & 82 & 15 \\
\hline 3.25 & - & - & - & 1914 & 99 & 18 \\
\hline 3.75 & - & - & - & 1895 & 118 & 21 \\
\hline
\end{tabular}

A. subarctica, A. sp.) are $-0.5 \%$ and $-4.7 \%$, respectively (Fig. 5). Species richness increases from 38.6 to 40.7 , DVC (mean 3.9) increases to $6.010^{8} \mathrm{~g}^{-1}$ at $0.75 \mathrm{~cm}$ depth, and the Mallomonas index increases from 25.6 to 35.7. Pliocaenicus bolshetokoensis is present at $14.9 \%$ on average in all samples, with no clear trend, whereas Achnanthidium minutissimum averages $8 \%$ and exhibits an increasing trend in the uppermost samples. Total beta diversity (BDTotal) is 0.17 ; LCBD varies between 0.09 and 0.16 , but none of the values is statistically different. CONISS cluster analysis shows a clear distinction between surface samples and samples from the lower part of the sediment core.

Sediment core PG2203 (Fig. 3b), from $36.1 \mathrm{~m}$ water depth, has $68 \%$ planktonic, $13 \%$ epiphytic, and $19 \%$ epipelic species (means of all counted samples). $\mathrm{Cy}$ clotella taxa are represented by $46.6 \%$ and Aulacoseira by $6.2 \%$, on average. The change in the mean abundance of Cyclotella species between three upper samples, from 0 to $4.5 \mathrm{~cm}$, and three lower samples, from 6 to $13.5 \mathrm{~cm}$, is 9.3\%. The differences from the same sample intervals for Aulacoseira groups 1 and 2 are $0.2 \%$ and $-2.4 \%$, respectively (Fig. 5). Species richness is 49.5 on average in all samples, with strong fluctuations (35.6-82.9), but no clear trend. DVC (mean 5.1) increases to $10.4 \times 10^{8} \mathrm{~g}^{-1}$ at $0.25 \mathrm{~cm}$ depth. The Mallomonas index only applies to the two uppermost samples (mean 17.5). Pliocaenicus
Fig. 3 Diatom assemblage changes in short sediment cores from Lake Bolshoe Toko. The red shaded area indicates the period of global industrialization starting in the mid-nineteenth century, as determined by ${ }^{210} \mathrm{~Pb}$ and ${ }^{137} \mathrm{Cs}$ dating. The blue area indicates samples used to represent pre-industrial values. Species occurrence is given as relative abundance (\%, scales vary to show rare taxa) and species richness as rarefied number of taxa. Planktonic/benthic ratio, Mallomonas index, and local contribution to beta diversity (LCBD) are also shown

bolshetokoensis is present at $13 \%$ on average, with a slight decrease in the uppermost sample (9.5\%). Achnanthidium minutissimum reaches $6.5 \%$ on average. BDTotal in the core is 0.20 and LCBD varies between 0.1 and 0.22 , but none of the values is statistically different. CONISS cluster analysis shows a clear distinction between the surface sample and the lower part of the sediment core.

Sediment samples from core PG2133 (Fig. 3c), collected at $26 \mathrm{~m}$ water depth, have $70 \%$ planktonic, $24 \%$ epiphytic, and $6 \%$ epipelic species. Cyclotella taxa are represented by $37.7 \%$ and Aulacoseira by $11.0 \%$, on average. The change in the mean abundance of Cyclotella species between two upper samples, from 0 to $3 \mathrm{~cm}$, and two lower samples, from 4 to $6.5 \mathrm{~cm}$, is $5.5 \%$. The differences from the same sample intervals for Aulacoseira groups 1 and 2 are $2.2 \%$ and $-4.9 \%$, respectively (Fig. 5). Species richness has a mean of 32.5 in all samples without any clear trends. DVC (mean 4.3 ) peaks at $8.5 \mathrm{~cm}$, with $9.6 \times 10^{8} \mathrm{~g}^{-1}$, then decreases, but peaks again at $0.5 \mathrm{~cm}$, with $6.4 \times 10^{8} \mathrm{~g}^{-1}$. Mallomonas is only present in the surface sample, giving an index value of 16.3. Pliocaenicus bolshetokoensis is present at $20.8 \%$ on average, with no clear trend, but a notably low value in the surface sample (15.3\%). Achnanthidium minutissimum accounts for $7.4 \%$ on average; Rossithidium pusillum is present in some samples (max. 4.6\%), showing a steady decrease towards the top of the core, before disappearing in the surface sample. BDTotal in the core is 0.16 and LCBD varies between 0.12 and 0.20 , but none of the values is statistically different. CONISS cluster analysis indicates a separation of the two uppermost samples.

In sediment samples from core PG2139 (Fig. 3d), taken from $12.1 \mathrm{~m}$ water depth, $37 \%$ of valves are planktonic, $47 \%$ epiphytic, and $16 \%$ epipelic species. Epiphytic species exhibit a slight increase in the record; planktonic species show a peak at $2.25 \mathrm{~cm}$. Cyclotella taxa are represented by only $1.7 \%$ and Aulacoseira by $18.9 \%$, on average. The 
a $\mathrm{PG} 2208$

a PG2



b PG2203



C ${ }^{P G} 2133$

C PG2133
$26.0 \mathrm{~m}$

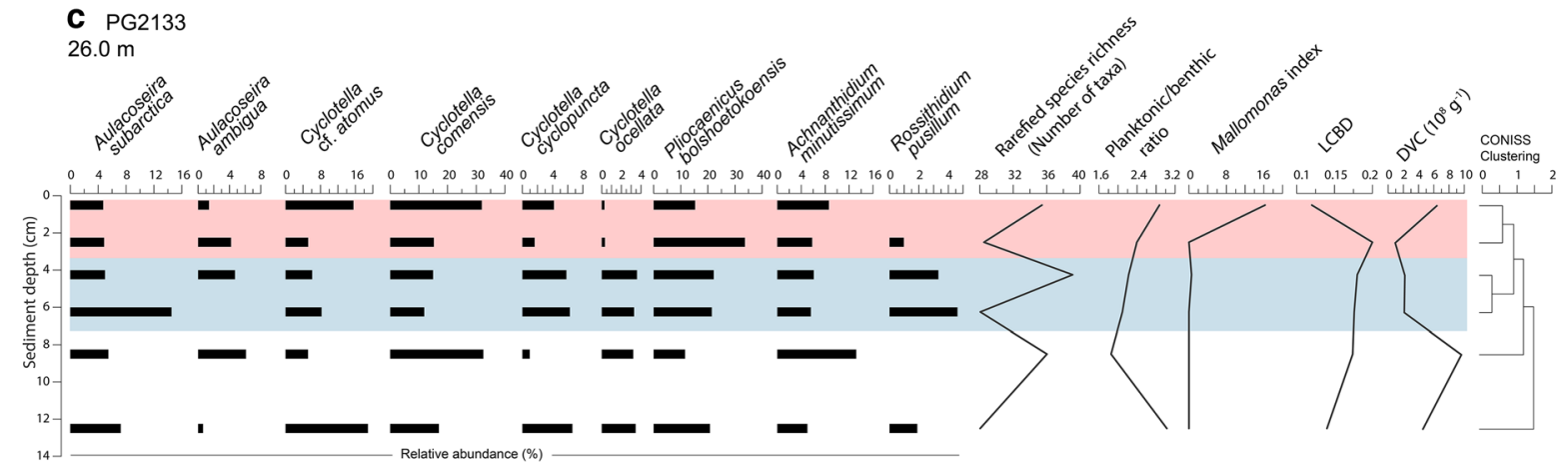

d PG2139

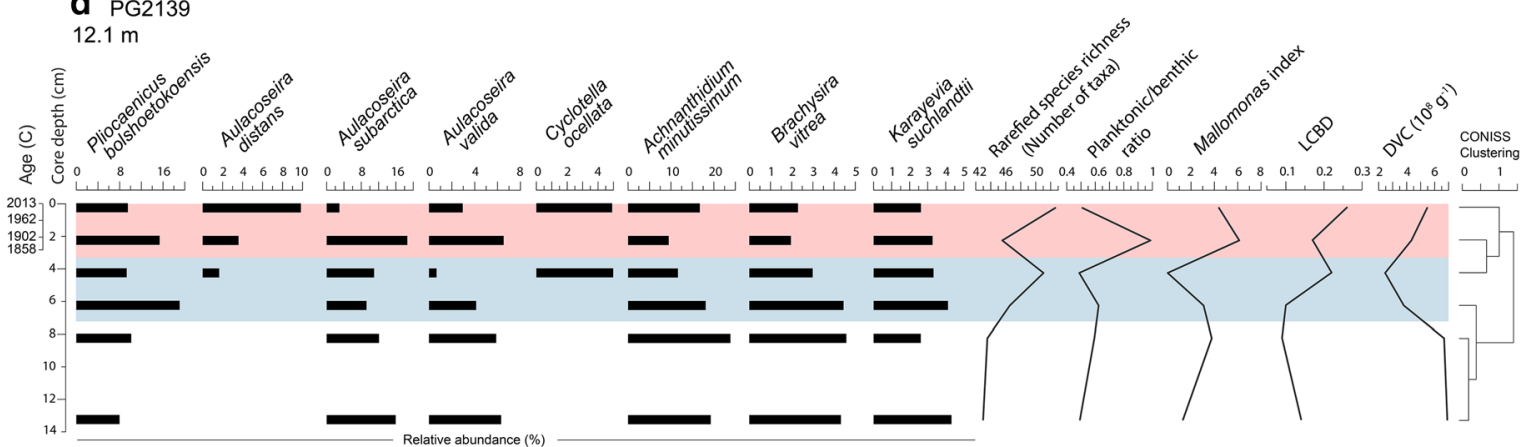


change in the mean abundance of Cyclotella species between two upper samples, from 0 to $2.5 \mathrm{~cm}$, and two lower samples, from 4 to $6.5 \mathrm{~cm}$, is negligible $(-0.03 \%)$. The differences from the same sample intervals for Aulacoseira groups 1 and 2 are $-8.2 \%$ and $0.4 \%$, respectively. Shallow site PG2139 therefore exhibits the strongest increase in Aulacoseira species (Fig. 5). Species richness has a mean of 47 in all counted samples, and an increasing trend, reaching its maximum value in the surface sample (52.6). DVC (mean 4.9) generally decreases from $6.7 \times 10^{8} \mathrm{~g}^{-1}(13.5-8 \mathrm{~cm})$, but slowly rises again and peaks at $5.5 \times 10^{8} \mathrm{~g}^{-1}$ at $0.25 \mathrm{~cm}$. The Mallomonas index shows an increase from the bottom samples (mean 2.0) to the two surface samples (mean 5.3). Pliocaenicus bolshetokoensis is present at $11.9 \%$ on average, with a maximum of $19.1 \%$ in the sample at $6.25 \mathrm{~cm}$. Achnanthidium minutissimum represents $16.5 \%$ on average, with a decrease towards the top, but has a high value in the surface sample. Brachysira vitrea and Karayevia suchlandtii both have mean values of $3.4 \%$, with $B$. vitrea exhibiting a clear decreasing trend to lowest values in the topmost two samples (mean 2.1\%). The BDTotal of 0.22 in this core is high compared to the other cores. LCBD values vary between 0.09 and 0.26 and LCBD is highest in the uppermost sample, which is significantly different from deeper sections of the core, indicating a unique species composition in the youngest sample. CONISS cluster analysis shows a clear distinction between surface samples and samples from the lower part of the sediment core.

\section{Geochemistry}

To gain reliable information on the chemical changes related to industrialization, the organic and inorganic geochemical composition was characterized for the top $30.5 \mathrm{~cm}$ of dated short core PG2203 (Fig. 4). The concentration of total organic carbon (TOC) is $5 \mathrm{wt} \%$ on average (3.7-6.5 wt \%), with only minor decreases of about $1 \%$ at $15 \mathrm{~cm}, 6 \mathrm{~cm}$, and in the uppermost $2 \mathrm{~cm}$. Mean nitrogen (N) is $0.45 \mathrm{wt} \%$ $(0.35-0.54 \mathrm{wt} \%)$. Changes in $\mathrm{N}$ are subtle and generally parallel changes in TOC between 30 and $4 \mathrm{~cm}$. In the uppermost $4 \mathrm{~cm}$ of the core, $\mathrm{N}$, in contrast to TOC, increases to maximum values. Accordingly, the TOC/ $\mathrm{N}_{\text {atomic }}$ ratio (9.58-15.6, mean 12.9) exhibits high values in the lower part of the core and distinctly lower values in the uppermost $3 \mathrm{~cm}$. Stable carbon isotope $\left(\delta^{13} \mathrm{C}\right)$ values, relative to the PDB standard, have a mean of $-26.85 \%$, with a minimum value of
$-27.18 \%$ and a maximum value of $-26.53 \%$. Values tend to decrease slightly and steadily from the bottom of the core towards $6 \mathrm{~cm}$, after which there is a remarkable increase in $\delta^{13} \mathrm{C}$, with high values in the uppermost $4 \mathrm{~cm}$ (mean - 26.73\%o).

\section{Discussion}

Chronological constraints

Because of very low sediment accumulation rates in lakes of northern cold regions, the sediment record in Lake Bolshoe Toko provides limited temporal resolution. Each $0.5 \mathrm{~cm}$ slice represents $\sim 15$ years of accumulation in PG2203 and $\sim 30$ years in PG2139, and the mean diatom sample resolution $(1.7 \mathrm{~cm})$ is $\sim 52$ years in PG2203 and $\sim 94$ years in PG2139 (Table 1). Hence, we used the short core data only for a top-bottom comparison, by averaging samples above and below the sediment depth dated to $1850 \mathrm{CE}$. This approach is supported by ${ }^{210} \mathrm{~Pb}$ results that suggest bioturbation is not a major problem. Nevertheless, another possible consequence of the low sedimentation rates is that even a small amount of mixing can blur environmental signals in the short cores. Therefore, we used the data only to detect qualitative changes and trends since the onset of industrialization.

Sediment accumulation rates differ between deeper and shallower sites (Table 1). We attribute this to winnowing (Crusius and Anderson 1995). Lake Bolshoe Toko is a flow-through lake with only one outflow and we suspect stronger currents in the northern shallower part. The central basin is deep and calm, so that more sediment particles settle, and are possibly augmented by focusing effects. Particle focusing may be intermittent, as suggested by the irregular nature, i.e. fluctuating activity, of the ${ }^{210} \mathrm{~Pb}$ record from PG2203 (Fig. 2a, b).

Diatom responses to post-industrial warming inferred at different water depths

The cores at water depths between 68.3 and $26 \mathrm{~m}$ (PG2208, PG2203, PG2133) reveal similar trends, with an increase in Cyclotella and decrease in Aulacoseira species during the mid-nineteenth century (Fig. 5), the approximate onset of the industrial period 


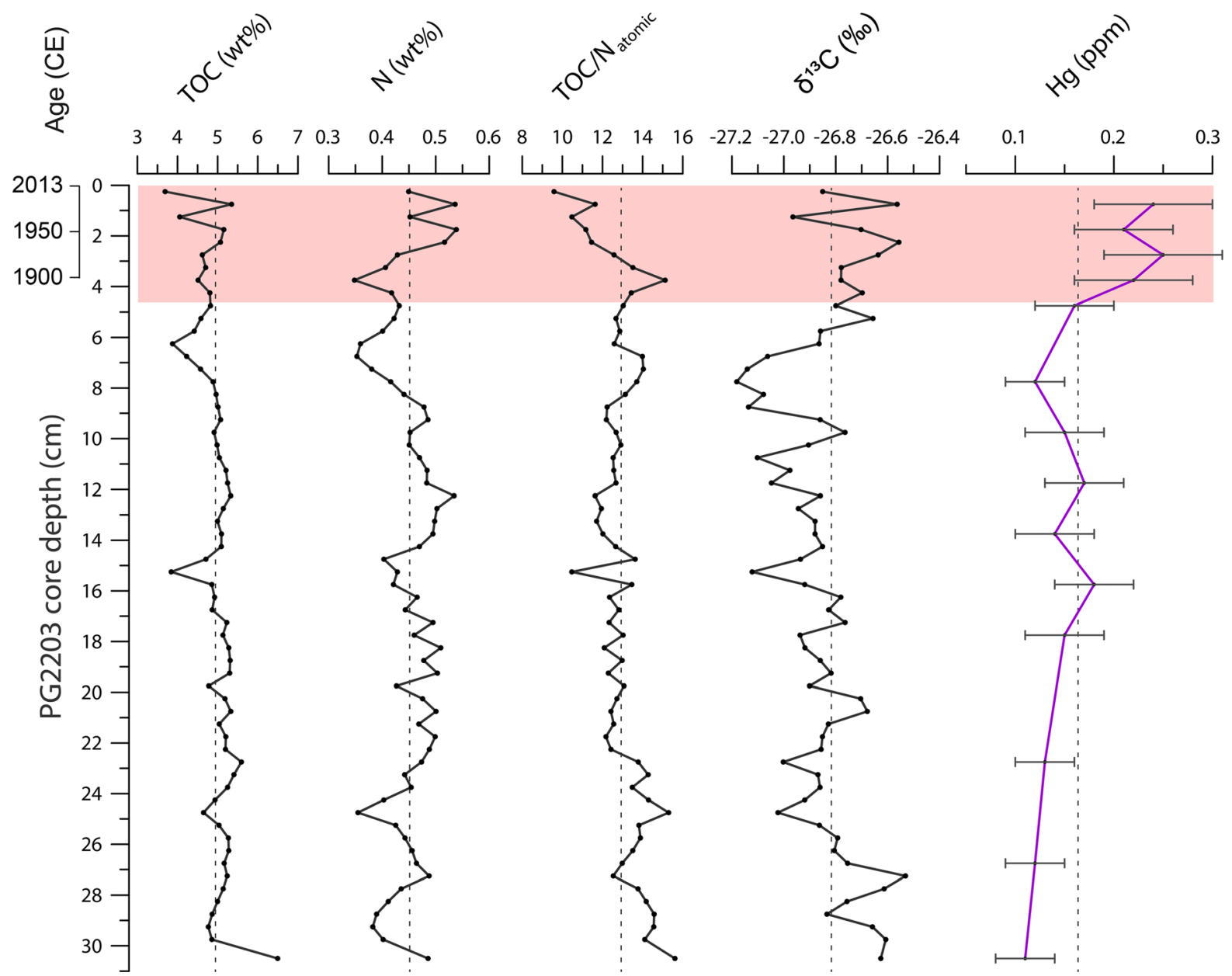

Fig. 4 Geochemical properties of sediment core PG2203, showing total organic carbon (TOC), nitrogen $(\mathrm{N})$, atomic TOC/ $\mathrm{N}$ ratios, stable carbon isotope values $\left(\delta^{13} \mathrm{C}\right)$, and mercury concentrations $(\mathrm{Hg})$ in parts per million. The red shaded area indicates the industrialization of the Northern Hemisphere,

(Abram et al. 2016). This general change in planktonic taxa is a response of deep-water pelagic groups to environmental forcing. The shifts in single species, as tested in the PCA biplots (Electronic Supplementary Material [ESM] Figs. 1-4), provide only limited potential for more precise inferences of ecological forcing. A careful interpretation of the PCA results reveals a slight tendency towards clustering of Cyclotella species (i.e. PG2203), and a slightly similar response for Pliocaenicus and some Aulacoseira species in PG2203 and PG2139 cores.

The genus Aulacoseira is abundant in deep, cool, and unstratified boreal lakes (Laing and Smol 2003). Species vary from euplanktonic (A. ambigua and $A$. starting in the mid-nineteenth century as determined by ${ }^{210} \mathrm{~Pb}$ and ${ }^{137} \mathrm{Cs}$ dating. Ages are given in common era next to core depths. Dashed lines indicate mean values for the whole sequence

subarctica) to tychoplanktonic (A. distans and A. valida) forms with strongly silicified, heavy, and thus rapidly sinking frustules, which require water turbulence to remain suspended in the photic zone (Gibson et al. 2003; Rühland et al. 2008). Cyclotella on the other hand represents small planktonic diatoms with less silicified and thus lighter frustules, with high surface area to volume ratios (Rühland et al. 2003). These taxa therefore prefer strong thermal stratification regimes and thrive under a warmer climate (Rühland et al. 2015; Smol et al. 2005). Moreover, Cyclotella sensu lato as a group can be used to detect recent warming in lakes that stratify (Reavie et al. 2017). Accordingly, diatom assemblage shifts at 


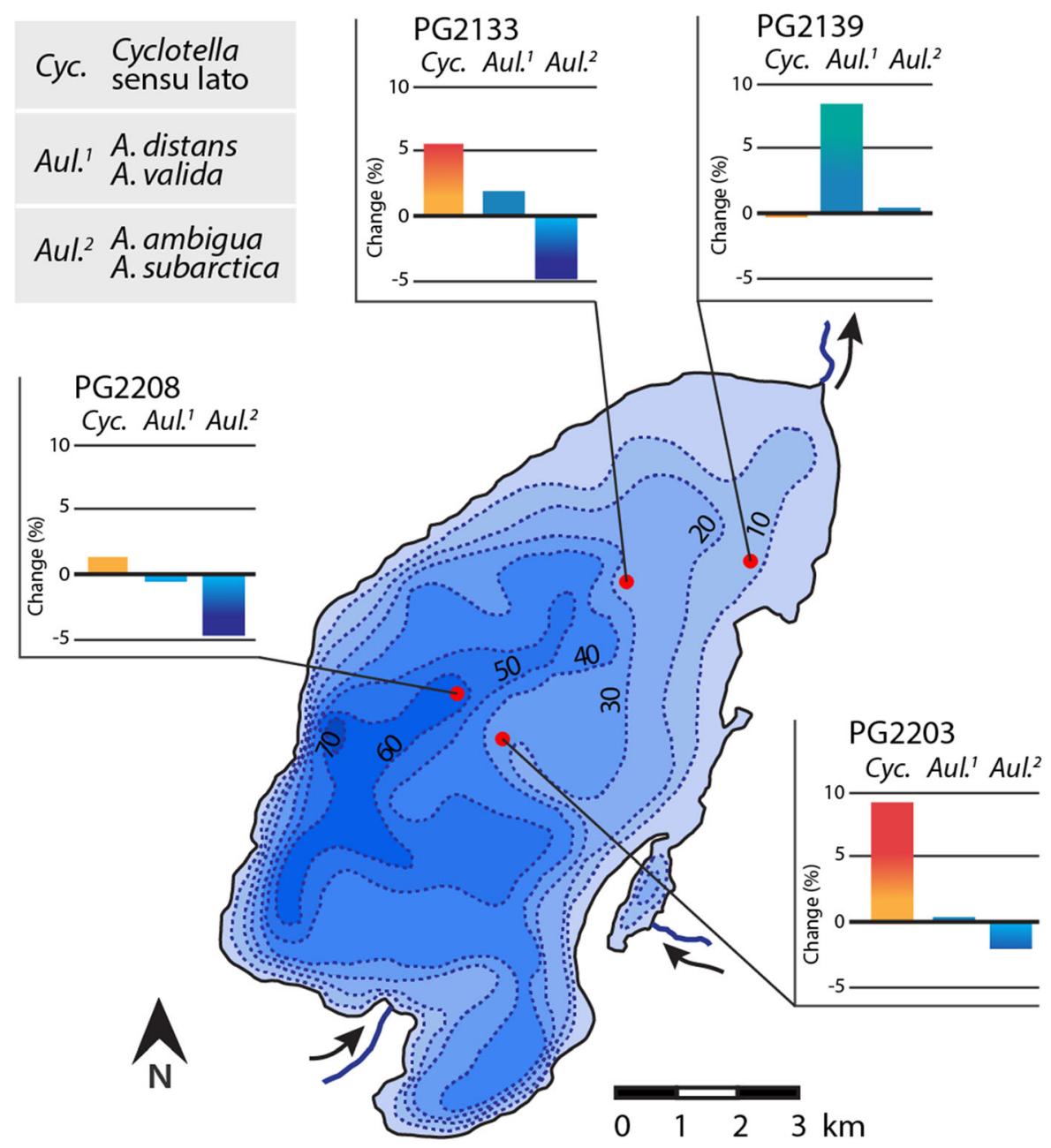

Fig. 5 Diatom assemblage changes at the onset of industrialization in the mid-nineteenth century in Lake Bolshoe Toko. Changes in Cyclotella (sensu lato) and two groups of Aulacoseira (Aul.), calculated as difference between mean abundance before and after $1850 \mathrm{CE}$, as estimated by ${ }^{210} \mathrm{~Pb}$ and ${ }^{137}$ Cs dating of cores PG2203 and PG2139 and mapped onto

deeper-water sites, from euplanktonic Aulacoseira ( $A$. group 2) to Cyclotella (Fig. 5), indicate prolonged thermal stratification (Rühland et al. 2015). Among other common driving factors, such as light availability, wind speed, turbidity, and nutrient availability, or a combination of these factors, diatom shifts were mainly related to the response of Lake Bolshoe Toko to increasing air temperature, associated with shorter ice cover and longer summer thermal stratification. Influence of recent atmospheric warming on planktonic diatoms, caused by stronger thermal stratification, has also been observed in Lake Baikal (Roberts cores PG2208 and PG2133. Genus Aulacoseira mainly consists of euplanktonic species (A. ambigua, A. subarctica and A. sp.) at deep sites (PG2203, PG2208). Shallow site PG2139 (and to a lesser degree intermediate site PG2133) reveals a higher proportion of tychoplanktonic A. distans and A. valida

et al. 2018) and in lakes of western Russia (Solovieva et al. 2008).

The slight increase in A. minutissimum observed in PG2208 (Fig. 3a), which is regarded as a pioneer species, can indicate an increase in available habitats, including for diatoms that have tychoplanktonic and benthic lifestyles, during longer growing seasons. In contrast to the deep-water sites, core PG2139 reveals how shallower-water communities respond to warming. A distinct increase in species richness suggests that the development of new habitats, possibly resulting from macrophyte growth associated with changes 
in light and nutrient availability during longer ice-free periods, leads to increasing diatom assemblage complexity (Rühland et al. 2015). At shallow site PG2139, euplanktonic A. subarctica still decreases (Fig. 3), while A. distans and A. valida increase (Fig. 5), as the latter species are considered littoral tychoplanktonic forms, often found in shallow waters with low transparency (Krammer and Lange-Bertalot 1986-1991). The observed lower total beta diversity of diatoms in deep-water sites, compared to higher diversity in the shallow-water site (PG2139), corresponds well to the findings of Stoof-Leichsenring et al. (2020). Diatom metabarcoding of sedimentary DNA from Bolshoe Toko revealed a negative correlation between diatom beta diversity and water-depth-related differences in habitat and light availability.

We attribute the DVC increase in surface samples of all cores, i.e. in planktonic communities at deeper sites, to enhanced productivity as a consequence of warming (Biskaborn et al. 2012; Douglas and Smol 2010). However, this trend was initially interrupted at shallower sites, likely because habitat changes and associated species turnover caused stress to the diatom community and thus led to lower reproduction rates.

Our interpretation of the observed shifts in diatom assemblages, following recent air temperature increases and associated reductions in the duration of the annual ice-cover, is supported by instrumental measurements of air temperature since 1960 at the TOKO RS weather station, $\sim 8 \mathrm{~km} \mathrm{NNE}$ of Lake Bolshoe Toko (ESM Fig. 5). According to the data from the National Oceanic and Atmospheric Administration (NOAA) Database (www.noaa.gov; station ID RSM00031137, TOKO RS) mean summer and winter air temperatures (MSAT, MWAT) increased steadily until the date of sampling in 2013. During that period, MSAT increased by $0.4{ }^{\circ} \mathrm{C}$ per decade and MWAT by $0.6{ }^{\circ} \mathrm{C}$ per decade, suggesting a strong influence on lake ice. Our sediment records suggest that the onset of atmospheric warming at Lake Bolshoe Toko occurred about 100 years before acquisition of meteorological data from the ground-based instrumental weather station began.

Geochemical impacts to the lake ecosystem at the onset of industrialization

Concentrations of mercury $(\mathrm{Hg})$ in sediment core PG2203 increased since the late-nineteenth century
(Fig. 4). $\mathrm{Hg}$ contamination in aquatic systems can come from atmospheric deposition, erosion sources, and urban, agricultural, mining, and combustion/ industrial discharges (Wang et al. 2004). We can dismiss significant impacts from the mining settlement $17 \mathrm{~km} \mathrm{NW}$ of the lake because it was established only two years before core retrieval. Analyses of $\mathrm{Hg}$ in sediments of Lake Baikal (Gelety et al. 2007) and other lakes (Jones et al. 2015; Lamborg et al. 2002) showed that $\mathrm{Hg}$ concentrations in sediments of remote natural lakes reflect variations in the $\mathrm{Hg}$ concentration in the atmosphere. In industrial areas, $\mathrm{Hg}$ adheres to aerosol particles and is transported over thousands of kilometers from its source for up to one year before being deposited (Lucotte et al. 1995). It has been reported that mercury in lake sediments is sufficiently immobile to generate historically reliable downcore records (Lockhart et al. 2000) and that high metal concentrations in Russian lake sediments are amplified by acidification trends (Moiseenko and Gashkina 2011). Therefore, we interpret the increasing upcore $\mathrm{Hg}$ concentrations in core PG2203 to reflect greater late-nineteenth century atmospheric $\mathrm{Hg}$ fallout in the catchment of Lake Bolshoe Toko as a consequence of industrialization in the Northern Hemisphere. The increase in $\mathrm{Hg}$ concentration by a factor of 1.6 in the lake deposits is low compared to other core studies in the Northern Hemisphere, which show twofold to sevenfold increases (Schuster et al. 2002). Nevertheless, total $\mathrm{Hg}$ concentrations are about double those from short sediment cores collected in Kamchatka (Jones et al. 2015). The Hg peak occurs at $2.75 \mathrm{~cm}$ (1931 CE), with slightly decreasing values afterwards, which could reflect a decrease in heavy metal pollution since the 1980s (Thevenon et al. 2011).

Diatom community responses to heavy metal contamination can induce changes in abundance of certain indicator species, for example, increases in Nitzschia (Pérès et al. 1997; Tlili et al. 2011). Samples from Lake Bolshoe Toko, however, show only minor changes of Nitzschia, around $0.5-1.6 \%$ in the cores from deep-water sites (PG2208, PG2203, PG2133), and slightly larger changes at the shallow site (PG2139), around 1.6-4.0\%, without clear increasing or decreasing trends. Thus, no impact of heavy metal contamination on the lake diatom assemblages can be deduced from the current data.

Parallel increases in values of $\delta^{13} \mathrm{C}$ and $\mathrm{Hg}$ (Figs. 4, 6) can indicate that less $\mathrm{C} 3$ plant material (Biskaborn 
et al. 2019a) and/or less terrestrial plant material is delivered to the sediments (Erlenkeuser et al. 1974). This raises the question of whether $\mathrm{Hg}$ is positively associated with algal-derived organic matter accumulation. An inverse relationship between $\delta^{13} \mathrm{C}$ and planktonic/benthic diatom ratios was reported by Wang et al. (2013). In our records, however, only core PG2208 exhibits a decreasing planktonic/benthic ratio, and it remains unclear if increasing $\delta^{13} \mathrm{C}$ values reflect autochthonous or allochthonous processes.

Increasing nitrogen concentrations coincide with decreasing ratios of organic carbon to nitrogen (TOC/ $\mathrm{N}_{\text {atomic }}$ ), indicating an increase in nitrogen loading independent from carbon input to the surface sediments (Figs. 4, 6). Higher ratios of TOC/ $\mathrm{N}_{\text {atomic }}$ in the southern end of the lake, compared to the northern end, however, suggest differences in catchment characteristics and a high supply of terrestrial organic matter from the Utuk River (Biskaborn et al. 2019a). High N favours rapid reproduction rate of small diatom species such as Cyclotella (Jordan and Bender 1973). Aulacoseira subarctica, on the other hand, is a better competitor when there is high silica loading (Gibson et al. 2003). Higher nitrogen availability enhances growth of some less silicified Cyclotella taxa, even though they compete with other phytoplankton such as Mallomonas (Fig. 3). Furthermore, nitrogen enhances macrophyte growth (Farmer 1990), which explains the slight increasing trend for epiphytic species in PG2139, also demonstrated by increases in alpha and beta diatom diversity.

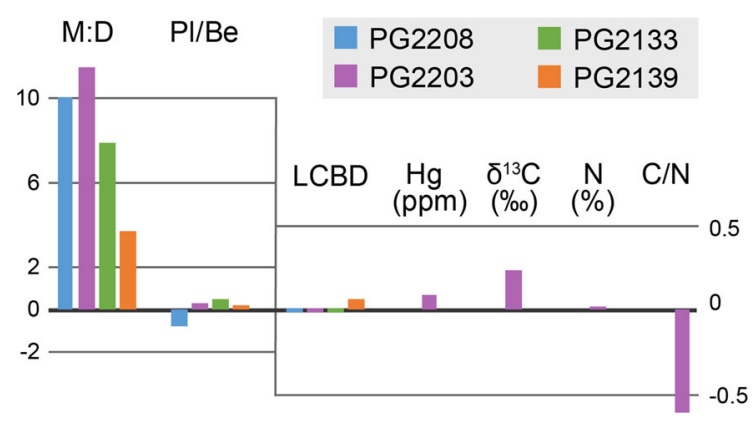

Fig. 6 Changes in diatom indicators and chemical composition expressed as differences between mean values before and after 1850 CE. Left axis: M:D, Mallomonas index; Pl/Be, planktonic to benthic diatom ratio. Right axis: $\mathrm{LCBD}$, local contribution to beta diversity; $\mathrm{Hg}$, mercury; $\delta^{13} \mathrm{C}$, stable organic carbon isotope values; $\mathrm{N}$, nitrogen; $\mathrm{C} / \mathrm{N}$ organic carbon to nitrogen ratio. IDs of coring sites are coded in colors
The delayed timing of nitrogen increase, starting ca. 1950 CE (Fig. 4), indicates that climate change was the first cause of observed diatom shifts (Korosi et al. 2020). Increased $N$ likely originated from a combination of greater catchment weathering inputs and direct atmospheric fallout of nitric acid aerosols (Gruber and Galloway 2008). The reliability of Lake Bolshoe Toko for capturing and preserving records of atmospheric fallout is demonstrated by the quality and consistency of the ${ }^{210} \mathrm{~Pb},{ }^{137} \mathrm{Cs}$ and ${ }^{241} \mathrm{Am}$ results.

Bioindicators in all short cores indicate secondary effects of catchment warming, i.e. a strong increase in the Mallomonas index (Figs. 3a-d, 6). Mallomonas is a group of flagellated golden-brown algae used as indicators of lake acidification (Smol et al. 1984) and nutrient enrichment (Munch 1980). Lake acidification is supported by a decrease in $R$. pusillum, an alkaliphilous species (Bigler and Hall 2002), in sediment cores PG2233 and PG2139, and it even disappears in the surface sample at the shallow-water site.

According to Kremleva and Moiseenko (2017), susceptibility of lakes to acidification is largely determined by the prevalence of silicic rocks in the catchment, which enable the inflow of acid-forming compounds. They also report that lakes in the northern and central taiga are the most susceptible to acidification among lakes in western Siberia. Given the geological setting of Bolshoe Toko, we believe that in spite of low precipitation in the region (ESM Fig. 5), the observed lowering of alkalinity occurred in the course of warming and atmospheric acid supply during industrialization in the Northern Hemisphere. It must be noted that parallel increases in air temperature and acidification make it difficult to attribute changes in diatom relative abundances to a single driver, and it is more likely that the community responded to the combined effects of both.

Vörösmarty et al. (2010) demonstrated that $80 \%$ of the world's population is exposed to threats of water security and associated declines in freshwater biodiversity, mostly related to densely settled areas with intense agriculture. In their study, remote areas such as Yakutia are subject to less threats because pollution comes mainly from atmospheric fallout. Nevertheless, our study demonstrates that even extremely remote freshwater ecosystems experienced human impact following the onset of nineteenth-century industrialization, with negligible delay. 


\section{Conclusions}

This investigation of oligotrophic freshwater Lake Bolshoe Toko revealed biogeochemical responses to climate change and industrial pollution in the Northern Hemisphere. Although there is almost no direct human impact on the lake, it has experienced changes forced by climate and long-range transport of human-generated pollutants. Small-scale changes in the lake started with the onset of industrialization in the mid-nineteenth century, the timing of which is supported by well-preserved anthropogenic contaminants such as mercury, which increased in the lake sediments by a factor of 1.6.

Effects of limno-ecological change can be attributed to climate change since $1850 \mathrm{CE}$, which drove shifts in the diatom community, followed by acidification, as indicated by increases in Mallomonas. Changes in planktonic diatom abundance suggest increasing summer stratification, likely a consequence of rising winter and summer air temperatures and associated shortening of the duration of lake-ice cover. Species indicative of macrophyte habitat availability and nutrient loading increased at some sites. Deepwater communities underwent changes in key planktonic taxa relative abundances, i.e. from euplanktonic Aulacoseira to Cyclotella species, within otherwise relatively stable species assemblages, and significant species turnover (beta diversity) was found only at the shallowest site, which generally had a higher diversity of available habitats to support different life forms.

Regional warming is supported by local meteorological data that cover only the last few decades. The sedimentary diatom records enabled us to place this regional warming into longer-term perspective, extending back to the second half of the midnineteenth century. Our findings underline the high sensitivity of remote boreal lakes to human-induced climate change and pollution.

Acknowledgements We thank Julia Sokolnikova for providing mercury analyses and Almut Dressler and Kim Funck for helping with diatom slide preparation and identification. We thank Hanno Meyer and Mikaela Weiner for help with stable carbon isotopes. This research was supported by the Russian Foundation for Basic Research (Grant No. 18-45-140053), Ministry of Science and Higher Education of the Russian Federation (Grant No. FSRG-20200019).
Open Access This article is licensed under a Creative Commons Attribution 4.0 International License, which permits use, sharing, adaptation, distribution and reproduction in any medium or format, as long as you give appropriate credit to the original author(s) and the source, provide a link to the Creative Commons licence, and indicate if changes were made. The images or other third party material in this article are included in the article's Creative Commons licence, unless indicated otherwise in a credit line to the material. If material is not included in the article's Creative Commons licence and your intended use is not permitted by statutory regulation or exceeds the permitted use, you will need to obtain permission directly from the copyright holder. To view a copy of this licence, visit http://creativecommons.org/licenses/by/4.0/.

Funding Open Access funding enabled and organized by Projekt DEAL.

Data availability The full dataset is available at PANGAEA (https://www.pangaea.de; Data Publisher for Earth \& Environmental Science).

\section{References}

Abram NJ, McGregor HV, Tierney JE, Evans MN, McKay NP, Kaufman DS, Thirumalai K, Martrat B, Goosse H, Phipps SJ, Steig EJ, Kilbourne KH, Saenger CP, Zinke J, Leduc G, Addison JA, Mortyn PG, Seidenkrantz M-S, Sicre M-A, Selvaraj K, Filipsson HL, Neukom R, Gergis J, Curran MAJ, Lv G, the PkC, (2016) Early onset of industrial-era warming across the oceans and continents. Nature 536:411-418

Ács E, Ari E, Duleba M, Dressler M, Genkal IS, Jako E, Rimet F, Ector L, Kiss TK (2016) Pantocsekiella, a new centric diatom genus based on morphological and genetic studies. Fottea 16:56-78

AMAP (2017) Snow, water, ice and permafrost in the arctic (SWIPA) 2017. Arctic monitoring and assessment programme (AMAP), Oslo, Norway, pp 1-269

Appleby PG, Nolan PJ, Gifford DW, Godfrey MJ, Oldfield F, Anderson NJ, Battarbee RW (1986) ${ }^{210} \mathrm{~Pb}$ dating by low background gamma counting. Hydrobiologia 143:21-27

Appleby PG, Richardson N, Nolan PJ (1992) Self-absorption corrections for well-type germanium detectors. Nucl Instrum Methods Phys Res Sect B 71:228-233

Battarbee RW, Jones VJ, Flower RJ, Cameron NG, Bennion H, Carvalho L, Juggins S (2001) Diatoms. In: Smol JP, Birks HJB, Last WM (eds) Tracking environmental change using lake sediments, vol 3. Terrestrial, algal, and siliceous indicators. Kluwer Academic Publishers, Dordrecht, pp 155-202

Bigler C, Hall RI (2002) Diatoms as indicators of climatic and limnological change in Swedish Lapland: a 100-lake calibration set and its validation for paleoecological reconstructions. J Paleolimnol 27:97-115

Birks HJB (2010) Numerical methods for the analysis of diatom assemblage data. In: Smol JP, Stoermer EF (eds) The 
diatoms: applications for the environmental and earth science. Cambridge University Press, Cambridge, pp 23-54

Biskaborn BK, Herzschuh U, Bolshiyanov D, Savelieva L, Diekmann B (2012) Environmental variability in northeastern Siberia during the last similar to $13,300 \mathrm{yr}$ inferred from lake diatoms and sediment-geochemical parameters. Palaeogeog Palaeoclimatol Palaeoecol 329:22-36

Biskaborn BK, Nazarova L, Pestryakova LA, Syrykh L, Funck K, Meyer H, Chapligin B, Vyse S, Gorodnichev R, Zakharov E, Wang R, Schwamborn G, Bailey HL, Diekmann B (2019a) Spatial distribution of environmental indicators in surface sediments of Lake Bolshoe Toko, Yakutia, Russia. Biogeosciences 16:4023-4049

Biskaborn BK, Smith SL, Noetzli J, Matthes H, Vieira G, Streletskiy DA, Schoeneich P, Romanovsky VE, Lewkowicz AG, Abramov A, Allard M, Boike J, Cable WL, Christiansen HH, Delaloye R, Diekmann B, Drozdov D, Etzelmüller B, Grosse G, Guglielmin M, IngemanNielsen $T$, Isaksen $K$, Ishikawa $M$, Johansson $M$, Johannsson H, Joo A, Kaverin D, Kholodov A, Konstantinov P, Kröger T, Lambiel C, Lanckman J-P, Luo D, Malkova G, Meiklejohn I, Moskalenko N, Oliva M, Phillips M, Ramos M, Sannel ABK, Sergeev D, Seybold C, Skryabin P, Vasiliev A, Wu Q, Yoshikawa K, Zheleznyak M, Lantuit H (2019b) Permafrost is warming at a global scale. Nat Commun 10:264

Biskaborn BK, Subetto DA, Savelieva LA, Vakhrameeva PS, Hansche A, Herzschuh U, Klemm J, Heinecke L, Pestryakova LA, Meyer H, Kuhn G, Diekmann B (2016) Late quaternary vegetation and lake system dynamics in northeastern Siberia: implications for seasonal climate variability. Quat Sci Rev 147:406-421

Cohen AS (2003) Palaeolimnology - the history and evolution of lake systems. Oxford University Press, Oxford, p 500

Crusius J, Anderson RF (1995) Sediment focusing in six small lakes inferred from radionuclide profiles. J Paleolimnol 13:143-155

Douglas MSV, Smol JP (2010) Freshwater diatoms as indicators of environmental change in the high arctic. In: Smol JP, Stoermer EF (eds) The diatoms: application for the environmental and earth sciences. Cambridge University Press, Cambridge, pp 249-266

Dray S, Blanchet G, Borcard D, Guenard G, Jombart T, Larocque G, Legendre P, Madi N, Wagner H (2016) Adespatial: multivariate multiscale spatial analysis. R Package Version 03:3

Erlenkeuser H, Suess E, Willkomm H (1974) Industrialization affects heavy metal and carbon isotope concentrations in recent Baltic Sea sediments. Geochim Cosmochim Acta 38:823-842

Farmer AM (1990) The effects of lake acidification on aquatic macrophytes - a review. Environ Pollut 65:219-240

Flower RJ, Ryves DB (2009) Diatom preservation: differential preservation of sedimentary diatoms in two saline lakes. Acta Bot Croat 68:381-399

Gabrielli P, Wegner A, Sierra-Hernández MR, Beaudon E, Davis M, Barker JD, Thompson LG (2020) Early atmospheric contamination on the top of the Himalayas since the onset of the European Industrial Revolution. Proc Natl Acad Sci USA 117:3967
Gelety VF, Kalmykov GV, Parkhomenko IY (2007) Mercury in the sedimentary deposits of Lake Baikal. Geochem Int 45:170-177

Genkal S, Gabyshev V (2018) New records of centric diatoms from Yakutia (Bolshoe Toko Lake): SEM morphology, ecology and distribution. Novosti sistematiki nizshikh rastenii 52:245-252

Genkal S, Gabyshev V, Kulilovskiy M, Kuznetsova I (2018) Pliocaenicus bolshetokoensis-a new species from Lake Bolshoe Toko (Yakutia, Eastern Siberia, Russia). Diatom Res 33(2):1-9

Gibson CE, Anderson NJ, Haworth EY (2003) Aulacoseira subarctica: taxonomy, physiology, ecology and palaeoecology. Eur J Phycol 38:83-101

Gruber N, Galloway JN (2008) An earth-system perspective of the global nitrogen cycle. Nature 451:293-296

Heinecke L, Mischke S, Adler K, Barth A, Biskaborn BK, Plessen B, Nitze I, Kuhn G, Rajabov I, Herzschuh U (2017) Climatic and limnological changes at Lake Karakul (Tajikistan) during the last similar to $29 \mathrm{cal} \mathrm{ka}$. J Paleolimnol 58:317-334

Hoff U, Biskaborn BK, Dirksen VG, Dirksen O, Kuhn G, Meyer H, Nazarova L, Roth A, Diekmann B (2015) Holocene environment of Central Kamchatka, Russia: implications from a multi-proxy record of Two-Yurts Lake. Global Planet Change 134:101-117

Hofmann G, Lange-Bertalot H, Werum M (2011) Diatomeen im Süßwasser-Benthos von Mitteleuropa. Ganter Verlag, Berlin

Holtgrieve GW, Schindler DE, Hobbs WO, Leavitt PR, Ward EJ, Bunting L, Chen G, Finney BP, Gregory-Eaves I, Holmgren S, Lisac MJ, Lisi PJ, Nydick K, Rogers LA, Saros JE, Selbie DT, Shapley MD, Walsh PB, Wolfe AP (2011) A coherent signature of anthropogenic nitrogen deposition to remote watersheds of the northern hemisphere. Science 334:1545

Hsieh TC, Ma KH, Chao A (2016) iNEXT: an R package for rarefaction and extrapolation of species diversity (Hill numbers). Method Ecol Evol 7:1451-1456

Huang S, Herzschuh U, Pestryakova LA, Zimmermann HH, Davydova P, Biskaborn BK, Shevtsova I, Stoof-Leichsenring KR (2020) Genetic and morphologic determination of diatom community composition in surface sediments from glacial and thermokarst lakes in the Siberian Arctic. J Paleolimnol 64:225-242

Imaeva L, Imaev V, Koz'min B, Mackey K (2009) Formation dynamics of fault-block structures in the eastern segment of the Baikal-Stanovoi seismic belt. Phys Solid Earth 45:1006-1011

IPCC (2018) Summary for policymakers. In: Masson-Delmotte V, Zhai P, Pörtner H, Roberts D, Skea J, Shukla P, Pirani A, Moufouma-Okia W, Péan C, Pidcock R (eds) Global warming of $15^{\circ} \mathrm{C}$. World Meteorological Organization, Geneva, p 32

Jones VJ, Rose NL, Self AE, Solovieva N, Yang H (2015) Evidence of global pollution and recent environmental change in Kamchatka, Russia. Glob Planet Change 134:82-90

Jordan RA, Bender ME (1973) Stimulation of phytoplankton growth by mixtures of phosphate, nitrate, and organic chelators. Water Res 7:189-195 
Konstantinov AF (2000) Environmental problems of lake Bolshoe Toko (in Russian). In: Zhirkov II, Pestryakova LA, Maksimov GN (eds) Lakes of cold environments, part V: resource study, resource use, ecology and nature protection issue. Yakutsk State University Publishing House, Yakutsk, pp 85-93

Kornilov BA (1962) Relief: the southeast suburbs of Aldan Mountains. Publishing House of Academy of Sciences of the USSR, Moscow (in Russian)

Korosi JB, Thienpont JR, Eickmeyer DC, Kimpe LE, Blais JM (2020) A paleolimnological approach for interpreting aquatic effects monitoring at the Diavik Diamond Mine (Lac de Gras, Northwest Territories, Canada). Lake Reserv Manag 36:297-313

Krammer K, Lange-Bertalot H (1986-1991) Bacillariophyceae Band 2/2. Gustav Fischer Verlag, Stuttgart

Kremleva TA, Moiseenko TI (2017) Evaluation of the pH buffer capacity of natural lake waters in Western Siberia: criteria of resistance to acidification. Geochem Int 55:559-568

Laing TE, Smol JP (2003) Late Holocene environmental changes inferred from diatoms in a lake on the western Taimyr Peninsula, northern Russia. J Paleolimnol 30:231-247

Lamborg CH, Fitzgerald WF, Damman AWH, Benoit JM, Balcom PH, Engstrom DR (2002) Modern and historic atmospheric mercury fluxes in both hemispheres: global and regional mercury cycling implications. Global Biogeochem Cycles 16:51-1

Lockhart WL, Macdonald RW, Outridge PM, Wilkinson P, DeLaronde JB, Rudd JWM (2000) Tests of the fidelity of lake sediment core records of mercury deposition to known histories of mercury contamination. Sci Total Environ 260:171-180

Lucotte M, Mucci A, Killaire-Marcel C, Pichet P, Grondin A (1995) Anthropogenic mercury enrichment in remote lakes of northern Quebec (Canada). In: Porcella DB, Huckabee JW (eds) Mercury as a global pollutant. Springer, Berlin, pp 467-476

Moiseenko TI, Gashkina NA (2011) Zonal features of lake acidification. Water Resour 38:47-62

Munch CS (1980) Fossil diatoms and scales of Chrysophyceae in the recent history of Hall Lake, Washington. Freshwat Biol 10:61-66

Nakov T, Guillory W, Julius M, Theriot E, Alverson A (2015) Towards a phylogenetic classification of species belonging to the diatom genus Cyclotella (Bacillariophyceae): transfer of species formerly placed in Puncticulata, Handmannia, Pliocaenicus and Cyclotella to the genus Lindavia. Phytotaxa 217(3):26

Oksanen F, Blanchet G, Kindt R, Legendre P, Minchin PR, O'Hara RB, Simpson GL, Solymos P, Stevens MHH, Wagner H (2012) Community Ecology Package "vegan"

Palagushkina O, Wetterich S, Biskaborn BK, Nazarova L, Schirrmeister L, Lenz J, Schwamborn G, Grosse G (2017) Diatom records and tephra mineralogy in pingo deposits of Seward Peninsula, Alaska. Palaeogeogr Palaeoclimatol Palaeoecol 479:1-15

Pepin N, Bradley RS, Diaz HF, Baraer M, Caceres EB, Forsythe N, Fowler H, Greenwood G, Hashmi MZ, Liu XD, Miller JR, Ning L, Ohmura A, Palazzi E, Rangwala I, Schoner W, Severskiy I, Shahgedanova M, Wang MB, Williamson SN,
Yang DQ (2015) Elevation-dependent warming in mountain regions of the world. Nat Clim Change 5:424-430

Pérès F, Coste M, Ricard F, Boudou A (1997) Effects of methylmercury and inorganic mercury on periphytic diatom communities in freshwater indoor microcosms. J Appl Phycol 9:215

R Core Team (2016) R: a language and environment for statistical computing

Reavie ED, Sgro GV, Estepp LR, Bramburger AJ, Shaw Chraibi VL, Pillsbury RW, Cai M, Stow CA, Dove A (2017) Climate warming and changes in Cyclotella sensu lato in the Laurentian Great Lakes. Limnol Oceanogr 62:768-783

Roberts SL, Swann GEA, McGowan S, Panizzo VN, Vologina EG, Sturm M, Mackay AW (2018) Diatom evidence of 20th century ecosystem change in Lake Baikal. Siberia PLOS ONE 13:e0208765

Rühland K, Paterson AM, Smol JP (2008) Hemispheric-scale patterns of climate-related shifts in planktonic diatoms from North American and European lakes. Glob Change Biol 14:2740-2754

Rühland KM, Paterson AM, Smol JP (2015) Lake diatom responses to warming: reviewing the evidence. $\mathrm{J}$ Paleolimnol 54:1-35

Rühland KM, Smol JP, Pienitz R (2003) Ecology and spatial distributions of surface-sediment diatoms from 77 lakes in the subarctic Canadian treeline region. Can J Bot 81:57-73

Ryves D, Juggins S, Fritz S, Battarbee R (2001) Experimental diatom dissolution and the quantification of microfossil preservation in sediments. Palaeogeog Palaeoclimatol Palaeoecol 172:99-113

Schuster PF, Krabbenhoft DP, Naftz DL, Cecil LD, Olson ML, Dewild JF, Susong DD, Green JR, Abbott ML (2002) Atmospheric mercury deposition during the last 270 years: a glacial ice core record of natural and anthropogenic sources. Environ Sci Technol 36:2303-2310

Shahgedanova M (2002) Climate at present and in the historical past. In: Shahgedanova M (ed) The physical geography of Northern Eurasia. Oxford University Press, Oxford, pp 70-102

Smol JP (1984) The statospore of Mallomonas pseudocoronata (Mallomonadaceae, Chrysophyceae). Nord J Bot 4:827-831

Smol JP, Charles DF, Whitehead DR (1984) Mallomonadacean microfossils provide evidence of recent lake acidification. Nature 307:628-630

Smol JP, Douglas MSV (2007) Crossing the final ecological threshold in high Arctic ponds. Proc Natl Acad Sci USA 104:12395-12397

Smol JP, Stoermer EF (2010) The diatoms: applications for the environmental and earth sciences. Cambridge Univ Press, Cambridge

Smol JP, Wolfe AP, Birks HJB, Douglas MSV, Jones VJ, Korhola A, Pienitz R, Rühland K, Sorvari S, Antoniades D, Brooks SJ, Fallu MA, Hughes M, Keatley BE, Laing TE, Michelutti N, Nazarova L, Nyman M, Paterson AM, Perren B, Quinlan R, Rautio M, Saulnier-Talbot E, Siitoneni S, Solovieva N, Weckstrom J (2005) Climate-driven regime shifts in the biological communities of arctic lakes. Proc Natl Acad Sci USA 102:4397-4402

Sobakina I, Solomonov N (2013) To the study of zooplankton of Lake Bolshoe Toko. Int J App Fund Res 8:180-182 
Solovieva N, Jones V, Birks JHB, Appleby P, Nazarova L (2008) Diatom responses to 20th century climate warming in lakes from the northern Urals, Russia. Palaeogeogr Palaeoclimatol Palaeoecol 259:96-106

Stewart KA, Lamoureux SF (2012) Seasonal and microhabitat influences on diatom assemblages and their representation in sediment traps and surface sediments from adjacent High Arctic lakes: Cape Bounty, Melville Island, Nunavut. Hydrobiologia 683:265-286

Stoof-Leichsenring KR, Dulias K, Biskaborn BK, Pestryakova LA, Herzschuh U (2020) Lake-depth related pattern of genetic and morphological diatom diversity in boreal Lake Bolshoe Toko, Eastern Siberia. PLoS ONE 15:e0230284

Thevenon F, Graham ND, Chiaradia M, Arpagaus P, Wildi W, Poté J (2011) Local to regional scale industrial heavy metal pollution recorded in sediments of large freshwater lakes in central Europe (lakes Geneva and Lucerne) over the last centuries. Sci Total Environ 412-413:239-247

Tlili A, Corcoll N, Bonet B, Morin S, Montuelle B, Bérard A, Guasch H (2011) In situ spatio-temporal changes in pollution-induced community tolerance to zinc in autotrophic and heterotrophic biofilm communities. Ecotoxicology 20:1823

Van Dam H, Mertens A, Sinkeldam J (1994) A coded checklist and ecological indicator values of freshwater diatoms from the Netherlands. Aquat Ecol 28:117-133

Vörösmarty CJ, McIntyre PB, Gessner MO, Dudgeon D, Prusevich A, Green P, Glidden S, Bunn SE, Sullivan CA,
Liermann CR, Davies PM (2010) Global threats to human water security and river biodiversity. Nature 467:555-561 Vyse SA, Herzschuh U, Andreev AA, Pestryakova LA, Diekmann B, Armitage SJ, Biskaborn BK (2020) Geochemical and sedimentological responses of arctic glacial Lake Ilirney, chukotka (far east Russia) to palaeoenvironmental change since $\sim 51.8 \mathrm{ka} \mathrm{BP}$. Quat Sci Rev 247:106607

Wang L, Mackay AW, Leng MJ, Rioual P, Panizzo VN, Lu H, Gu Z, Chu G, Han J, Kendrick CP (2013) Influence of the ratio of planktonic to benthic diatoms on lacustrine organic matter $\delta 13 \mathrm{C}$ from Erlongwan maar lake, northeast China. Org Geochem 54:62-68

Wang Q, Kim D, Dionysiou DD, Sorial GA, Timberlake D (2004) Sources and remediation for mercury contamination in aquatic systems-a literature review. Environ Pollut 131:323-336

Wang R, Zhang Y, Wuennemann B, Biskaborn BK, Yin H, Xia F, Zhou L, Diekmann B (2015) Linkages between Quaternary climate change and sedimentary processes in Hala Lake, northern Tibetan Plateau, China. J Asian Earth Sci 107:140-150

Zhirkov I, Trofimova T, Zhirkov K, Pestryakova L, Sobakina I, Ivanov K (2016) Current geoecological state of Lake Bolshoe Toko. Int J App Fund Res 8:208-213

Publisher's Note Springer Nature remains neutral with regard to jurisdictional claims in published maps and institutional affiliations. 